\title{
TIMELINESS OF NATIONAL ARMED FORCE PERSONNEL'S TRAINING IN THE FIELD OF BORDER SURVEILLANCE IN THE VIEW OF COOPERATION BETWEEN NATIONAL ARMED FORCES AND STATE BORDER GUARD
}

\author{
Valentīns Buls ${ }^{1}$, Oḷegs Ignatjevs ${ }^{2}$ \\ ${ }^{1} \mathrm{Mg}$. Paed, Docent of Military and Physical Education Subjects Department of the \\ State Border Guard College, e-mail: valentins.buls@rs.gov.lv, Rēzekne, Latvia \\ ${ }^{2}$ Bc. Phil., Assistant of Military and Physical Education Subjects Department of the \\ State Border Guard College, e-mail: olegs.ignatjevs@rs.gov.lv, Rēzekne, Latvia
}

\begin{abstract}
In the view of modern tendencies, the cooperation between state armed institutions is extremely crucial. As an example could be mentioned the reaction of French government on the terrorist attack in Paris in the year 2015 - both, army and police, in close cooperation made a contribution solving this challenge. In the scale of Latvia the cooperation between National Armed Forces and State Border Guard could solve such problems like lack of personnel and equipment in State Border Guard. The aim of the current paper is to give insight in such themes as legal basis of the mentioned cooperation, the possibilities of involving National Armed Forces personnel in border surveillance, the possibilities of National Armed Forces personnel's training in the field of border surveillance and possibilities for development of such training and make short summary in these topics. This was done by methods of analysis, open source research and comparative analysis. Among other conclusions, authors of the current paper draw a conclusion that cooperation between National Armed Forces and State Border Guard is effective but the possibilities of National Armed Forces personnel's training should be improved in the way mentioned in the paper.
\end{abstract}

Keywords: Armed Forces, border security, cooperation, legal basis, training.

\section{Introduction}

The tendencies of modern world development offer society not only comfort, but also huge risks. For example risks as international crime, cybercrime, terrorism etc. In order to furnish legal and legitimate power, states of the world usually relay on job of competent institutions. Often these institutions cooperate. As an example could be mentioned a French government answer on terrorist attack in Paris in 2015. In this case army and police units were working together ("Paris attacks: French police launch raids as military strikes Isis in Syria", 2015). Such cooperation plays also a different role: a role of creating a balance of force. I.e.: in democratic states police tends to use minimal force and military - to use maximum force (Friesendorf, 2013). In such situation as a terrorist attack such balance of force is extremely important.

6

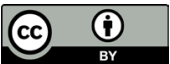


Such cooperation could be crucial in Latvia, considering special aspects of the job and the lack of personnel in National Armed Forces (further NAF) and in Ministry of Interior (further - MoI). For example the lack of personnel continues to grow in State Border Guard (further - SBG). Thus in 2018 there was lack of 233 border guards, which was $5-6 \%$ of total number of officials ("Uz Latvijas robežas trūkst vairāk nekā 230 robežsargu", 2018). Moreover, according to State Border Guard chef's interview, already in 2019 there was 8\% lack of personnel in State Border Guard ("Valsts robežsardzē pieaug darbinieku trūkums", 2019). Concluding, it is understandable that mentioned institutions should have an opportunity to enlarge their resources in case of necessity.

As it could be seen, the topicality of the current paper is undeniable authors made an analysis of effectiveness of cooperation in the field of border surveillance. This is extremely important to improve the effectiveness of State Border Guard. Also the current paper defines the competence of Latvian National Guard personnel (as a part of National Armed Forces) in the field of border surveillance and ways how it could be improved.

\section{Legal Basis}

In order to understand the fields of cooperation between National Armed Forces and State Border Guard, one should address according legal basis. The order how Latvian National Guard -the significant part of NAF provides support to state institutions, determines the regulation Nr.936 of the Cabinet of Ministers on $9^{\text {th }}$ of October 2010 "Regulation how Latvian National Guard provides support to state and self-administration institutions for preventing law violations and public security safeguarding" ("Valsts robežsardzē pieaug darbinieku trūkums", 2019) The cooperation in border surveillance in its turn is being regulated by multiagency treaty Nr.162 between State Border Guard and National Armed Forces on $12^{\text {th }}$ of May 2012 (Multiagency treaty Nr.162, SL-217-5, 2012). Both regulations specify the order how State Border Guard and National Guard cooperate in case of renewal of border control on internal borders and in case of pursuing a suspect in illegal border crossing. As one can see, both regulations are aimed on overcoming a personnel lack in SBG. It is crucial because in timely case the renewal of border control on internal borders could be a challenge to State Border Guard with its current resources. According to mentioned regulations in such case the common patrols of State Border Guard and National Guard personnel would be made to ensure the effective border surveillance. In these patrols National Guard soldiers would be subordinated to border guard officials. 
Performing border surveillance a number of administrative violations are constantly stated by State Border Guard officials. According to Latvian Administrative violation code, investigation of border security violations is under SBG competence (Administrative violations code of the Republic of Latvia, 1985). The same will be regulated by Law of Administrative responsibility (Law of administrative responsibility, 2018). On the other hand, NAF or National Guard is not competent in these cases. Thus the effective border surveillance could not be imagined if it would be performed only by NAF personnel. This fact approves necessity of common patrols of National Guard and SBG officials. Such patrols could be even more effective if NAF personnel would be adequately trained in the field of border surveillance.

In addition to previous according to Law of State Border Guard the officials are licensed to use the technical means, vessels and aviation of National Armed Forces (State Border Guard law, 1998). Thus State Border Guard can reinforce its technical resources.

On the other hand, the legal basis is also aimed on the National Armed Forces resources reinforcement with the help of State Border Guard capacity. Thus the Law of National Armed Forces article 3 part 3 states that in case of war SBG is included into NAF structure (National Armed Forces law, 1999). In this case the SBG personnel are subordinated to NAF command. The Law of State Border Guard, article 13 part 1, on its turn, states, that one of the tasks of State Border Guard is to ward off armed assaults on Latvia in cooperation with National Guard (State Border Guard law, 1998). As it could be seen in case of war State Border Guard replenishes National Armed forces with its personnel and technical resources. This could strengthen the combat capacity of NAF because SBG officials are adequately trained and armed. The accordance of weapons and training to NATO standards provides the National Armed Forces. This is witnessed by the process of rearming of SBG and by participation of its officials in military trainings and exercises. Concluding, one can notice that cooperation in war time is tended to the strengthening of combat power of NAF. Taking into consideration the standardisation of weapons and training this cooperation could be effective to achieve according goals.

Concluding from previous facts one can state that in case of necessity SBG has a good possibility to enhance its capacity with the help of NAF resources. But due to the difference in duty specifics it couldn't be possible to use NAF personnel in border surveillance independently. To do so, these personnel should be adequately trained. This training should be provided by State Border Guard. This procedure is stated in the multiagency treaty between NAF and SBG (Multiagency treaty Nr.162, SL-217-5, 2012). 


\section{The use of armed forces personnel in border surveillance}

As it was mentioned before, the use of NAF or National Guard in border surveillance would effectively enhance capacity of SBG in case of necessity. This conclusion is based not only on theoretical data, but it could be approved with help of international examples and recent example of Latvia using National Guard personnel in border surveillance during COVID-19 pandemic.

The experience of Hungary could be mentioned as first example. In year 2015 Hungary faced huge migratory crisis. During this year there were 441,515 cases of illegal border crossing cases (Migration Issues in Hungary, 2018). As a result Hungarian government made decision to build a fence and assign army units to perform border surveillance and fight the migration flow (Hungary beefs up border with army, warns migrants to stay away, 2015). Statistics show that this step helped to reduce the number of illegal border crossings from 274 persons a day at the beginning of summer 2015 to 10 persons a day at the end of the year (Migration Issues in Hungary, 2018). Thus we can conclude that multiagency treaty between Latvian State border guard and National armed force is extremely timely and in perspective could help to deal with a migratory crisis if Latvia would ever face one.

Latvia also faced irregular migration grows in 2015 (Salīdzinošā robežpārkāpumu statistika Baltijas reǵiona valstīs, 2016) but SBG was able to deal with this challenge by itself. Nevertheless the scenario of cooperation between SBG and NAF was played during common exercise. This exercise was held in Daugavpils regional board in 24-26 February 2017 (Order Nr.297 of State Border, 2017). Scenario was based on the border control renewal on Latvian- Lithuanian border. Having made the analysis of the exercise, responsible officials made a number of conclusions. Parts of these conclusions are timely for the current paper:

- The use of technical resources of National Guard was effective to perform border surveillance in remote regions.

- There were no standard operation plans for common checkpoints.

- The methods of trespassers' apprehension were defective (Order Nr.802 of State Border Guard, 2017).

In March 2020 this scenario was performed in real situation because of the COVID-19 pandemic. Latvian government made decision to stop border crossing on all state borders and to enhance border surveillance. State Border Guard was reinforced by National Guard resources (Bruṇotie spēki sniedz atbalstu Valsts robežsardzei Covid-19 izplatības ierobežošanā, 2020). According to the agreement, National Guard provided at least 100 soldiers with off-road vehicles (Bruņotie spēki turpinās sniegt atbalstu Valsts 
robežsardzei Covid-19 izplatības ierobežošanā, 2020). This decision made it possible to renew border control on Lithuanian and Estonian borders and to enhance border surveillance on Russian and Belarus borders. Thus Latvian government reduced the risk of virus spreading and cross-border crime enhancing. It is too early to speak about the results of such action because the crisis is not over and it is not possible to compare the actions of competent institutions statistically.

It could be concluded that use of National Guard personnel in border surveillance is effective. But the competence of these personnel is imperfect. Thus the training of National Guard personnel should be improved to exclude a possibility of failure in case of situation were National Guard personnel would be used in border surveillance.

\section{The possibilities of NAF personnel training in the field of border surveillance}

As it was mentioned before, the use of NAF personnel is an efficient method to improve the border surveillance effectiveness. But taking into consideration the difference in duty specifics, the lack of competence of NAF personnel in the field of border surveillance is obvious.

As it was mentioned before, the National Guard does not perform investigation of administrative violations. Thus it is necessary to train NAF personnel only in fields of SBG duty basis and border surveillance tactics. According to results of SBG and National Guard common exercise, the training in tactics of trespassers' tracking and apprehension should be intensified (Order Nr.802 of State Border Guard, 2017).

In order to progress requirements of multiagency treaty and to provide knowledge to NAF personnel (Multiagency treaty Nr.162 SL-217-5, 2012), State Border Guard college provide e- training for NAF personnel according to following themes: "Obligations and actions of National Guard personnel in case of renewal of border control on internal borders" and "Obligations and actions of National Guard personnel in case of pursuing a suspect in illegal border crossing" (Informācija zemessargiem, 2020). Also, responding to COVID-19 pandemic and border control enhancing, State Border Guard introduced a theoretic training program for National armed force personnel. This short training program is planned for 4 hours of individual study and includes such themes as Legal basis, Use of force and weapons, Service organisation, Border guard tactics (Order Nr.505 of State border guard, 2020). Thus SBG progress requirement in NAF personnel training according to mentioned multiagency treaty.

National Guard is not often involved in border surveillance thus individual and e- training is enough to give theoretical knowledge to the 
personnel. But, as it was stated before, the practical training should be improved because involving National Guard personnel without it could lead to a failure performing a border surveillance task. According to this authors of the current paper suggest to introduce a qualification course (or introduce the "train the trainer" method) in the field of border surveillance tactics for National Guard personnel. This would improve the competence of involved personnel in the mentioned field.

\section{Suggestions for improvement of NAF personnel training in the field of border surveillance}

As it was shown in the current paper, SBG organize theoretical training course for National Guard to implement the requirements of the multiagency treaty Nr.162. To make this training more effective, authors of current research suggest developing a practical training program. This program should introduce a basic border surveillance tactics for the National Guard personnel. The development of such training program is not possible in the scale of current paper and should be made within a separate research. The authors will give suggestions for introducing the program. Suggestions will be made on the basis of personal experience in border surveillance, on participation in FRONTEX joint operation and on the basis of current theoretical training programs.

First of all it is essential to teach the NAF personnel types of assignments used in border surveillance. These could be Patrol, Checkpoint, Observation post and Ambush assignments. Reviewing this topic it is necessary to teach the personnel the obligations and restrictions of these assignments and the respective legislation (e.g. corresponding articles of the Traffic law for the Checkpoint assignment).

Secondly, it is necessary to introduce technical means, equipment and special means used in border surveillance. It is important to speak about tactics and legislation corresponding to these means (e.g. when and how handcuffs should be used).

Thirdly, the personnel should be trained in the tactics of patrol, especially on foot. This topic should include skills in illegal border crossing detection and the basics of man tracking.

Fourthly, it is necessary to touch upon the control of border land and border area regime. The accent should be put on legislation and administrative case investigation. Considering the fact that National Guard doesn't have rights for administrative investigation, this topic should be more familiarizing. After this part of training the personnel should know the requirements of border land and border area regime and how a person can be granted an access to stay there. 
Fifthly, it is essential to train the tactics of an ambush. It is important because this assignment is the most effective for trespassers' apprehension. Especially if the risk analysis was made correctly and the law enforcement institution has the information about a probable border violation place.

Finally, it would be useful to introduce the personnel the known tactics of trespassers, both irregular migrants and smugglers. It would improve the patrolling, detecting the violation and tracking skills of the personnel.

Authors of the current paper have an opinion that it would be possible to develop a 40-hour-long qualification course according to the topics mentioned above. This training would be timely for National Guard personnel that is planned to reinforce State Border Guard in a case of emergency. It would be effective to introduce such qualification course for NAF instructors to implement a "train a trainer" method. Such method, on its turn, would allow training a bigger number of personnel on the same period of time. Taking into consideration the constant situation of trainees, the specifics and timeliness of training such qualification course could be held not only in State Border Guard College, but also in regional boards of the State Border Guard. Considering their duty the border guards in the regional boards are mode acquainted with tactics of trespassers and could become effective trainers for the National Guard personnel.

\section{Conclusions and suggestions}

Making current research the authors came into following conclusions and made following suggestions:

In case of emergency Latvian State Border Guard is able to reinforce its capacity with the help of National Armed Forces' resources (both personal and technical).

Due to differences in duty specifics it wouldn't be possible to implement National Guard personnel in border surveillance directly and without SBG supervision.

State Border Guard College provide theoretical qualification course in border surveillance for National Guard personnel to improve the cooperation between two institutions.

Due to the fact that National Guard personnel is not often implemented in border surveillance, the authors conclude that e- training for corresponding personnel is enough to sustain minimal knowledge in the sphere. But practical training should be improved.

Authors of the current research suggest introducing a practical qualification course in the sphere of border surveillance tactics for National Guard personnel with possibility of "train the trainer" method. Such course 
would improve competence of the personnel that is planned for State Border Guard reinforcement.

Qualification course for National Guard personnel should include such topics as Types of border guards' assignments, Tactics of border surveillance, Corresponding legislation, Necessary equipment, Methods of primary investigation, Information about border land and border area regime, Most common trespassers' tactics. International Intervention and the Use of Force: Military and Police Roles

\section{References}

1. Code of High Council (1985) Administrative violations code of the Republic of Latvia. Latvijas Padomju Sociālistiskās Republikas Augstākās Padomes un Valdības Ziṇotājs, 51.

2. FRIESENDORF, C. (2012). International Intervention and the Use of Force: Military and Police Roles. Switzerland, Geneva: DCAF.

3. Hungary beefs up border with army, warns migrants to stay away (2015). Retrieved January 6, 2020 from https://www.reuters.com/article/us-europemigrants-hungary-law/hungary-beefs-up-border-with-army-warns-migrants-tostay-away-idUSKCNORL1K220150922

4. Informācija zemessargiem Retrieved January 1, 2020 from 195.13.183.215/moodle/

5. Law of the Parliament of the Republic of Latvia, Law of administrative responsibility (2018). Latvijas Vēstnesis, 225.

6. Law of the Parliament of the Republic of Latvia, National Armed Forces law. (1999). Latvijas Vēstnesis, 388/389.

7. Law of the Parliament of the Republic of Latvia, State Border Guard law (1998). Latvijas Vēstnesis.

8. Migration Issues in Hungary (2016). Retrieved January 6, 2020 from https://www.iom.hu/migration-issues-hungary

9. Order Nr.297 of State Border Guard on 20.02.2017 On exercise "Border control renewal on Latvian- Lithuanian border"

10. Order Nr.802 of State Border Guard on 17.05.2017 On State Border Guard and National Guard common exercise in State Border Guard Daugavpils regional board.

11. Paris attacks: French police launch raids as military strikes Isis in Syria (2015).

Retrieved January 3, 2020 from

https://www.theguardian.com/world/2015/nov/15/paris-attacks-car-foundwith-kalashnikovs-as-gunmans-relatives-questioned

12. Regulation Nr.936 of the Cabinet of ministers of the Republic of Latvia on 09.10.2010 Regulation how Latvian National Guard provides support to state and self-administration institutions for preventing law violations and public security safeguarding. (2010). Latvijas Vēstnesis, 160.

13. Salīdzinošā robežpārkāpumu statistika Baltijas regiona valstīs. Retrieved January 6, 2020 from http://www.rs.gov.lv/index.php?id=1031\&top=-6\&rel=3930

14. Treaty of State Border Guard and National Armed Forces on 2012 Multiagency treaty Nr.162, SL-217-5. 
15. Uz Latvijas robežas trūkst vairāk nekā 230 robežsargu (2018). Retrieved January 3, 2020 from https://www.lsm.lv/raksts/zinas/latvija/uz-latvijas-robezas-trukstvairak-neka-230-robezsargu.a280961/

16. Valsts robežsardzē pieaug darbinieku trūkums (2019). Retrieved January 6, 2020 from https://www.apollo.lv/6806367/valsts-robezsardze-pieaug-darbiniekutrukums-to-viskritiskak-izjut-lidosta-riga 